\title{
Sobre a capa
}

Aluna do $1^{\circ}$ ano do Ensino Fundamental, com 7 anos. Ela e grande parte dos seus amigos vivem o desafio de aprender em um sistema educacional precário, realidade de Moçambique e da Vila de Moma onde vivem.

Ela faz parte de um grupo de 49 alunos de um projeto de alfabetização desenvolvido por missionários brasileiros que propõe uma aprendizagem alternativa dentro dessa realidade. 0 Murima Wa Mwana (Coração de Criança na língua local) conta com o auxílio de voluntários locais para garantir o acompanhamento individual e integral na educação das crianças e adolescentes.

Nossa esperança é que o futuro desses pequenos seja em um mundo onde tenham direito à ternura e à alegria, à saúde e à escola, ao pão e à paz, ao sonho e à beleza.

Victória Holzbach

vikaholzbach@hotmail.com 
